\title{
The effects of dietary acid stress on bone metabolism in young ovariectomized and intact rats
}

\author{
By M. E. KUNKEL, Z. K. ROUGHEAD, E. A. NICHTER AND J. M. NAVIA \\ Department of Food Science, Clemson University, Clemson, SC 2963I, USA
}

(Received 13 August 1984 - Accepted 13 August 1985)

\begin{abstract}
1. Two studies were performed to determine the effects of acid stress and ovariectomy on bone metabolism in young rats. In Expt 1, eighteen female weanling Sprague-Dawley-descended rats were ovariectomized, placed in one of three dietary groups and given a diet containing $(\mathrm{g} / \mathrm{kg}): 6$ calcium and 3,6 or 12 phosphorus for 10 weeks. In Expt 2, thirty-two female weanling Sprague-Dawley-descended rats were ovariectomized, and thirty-two were left intact. Eight rats from each group were given a diet containing $(\mathrm{g} / \mathrm{kg}): 6 \mathrm{Ca}$ and $3 \mathrm{P}, 12 \mathrm{P}, 3 \mathrm{P}+1 \mathrm{~S}$ or $3 \mathrm{P}+20$ ammonium chloride for 10 weeks.

2. Feeding diets containing $12 \mathrm{~g} \mathrm{P} / \mathrm{kg}$ resulted in decreased serum $\mathrm{Ca}$ and increased urinary $\mathrm{P}$ with no changes in femur composition. Feeding high-sulphate and ammonium chloride diets resulted in increased urinary $\mathrm{Ca}$ and, when combined with ovariectomy, lower femur $\mathrm{Ca}$ and $\mathrm{P}$ with no changes in femur hydroxyproline or hexosamines.

3. The findings reflect the more rapid turnover of the amorphous calcium phosphate salts found in greater amounts in bones of younger animals than for more stable apatitic crystals that predominate in bones of older animals.
\end{abstract}

A contributing factor in human osteoporosis has been suggested to be the long-term ingestion of an acid ash diet (Wachman \& Bernstein, 1968). The increased incidence of osteoporosis with age may represent, in part, the results of a life-long utilization of the buffering capacity of the basic salts of bone for the constant stress on $\mathrm{pH}$ homeostasis. Phosphate, ammonium chloride and sulphate are compounds which form acids on digestion and thus may be associated with utilization of bone as a buffer.

Draper et al. (1972) found that a dietary $\mathrm{Ca}: \mathrm{P}$ value of $1: 2$ depressed plasma $\mathrm{Ca}$ concentrations sufficiently to cause a stimulation of parathyroid hormone (PTH) secretion and an increased bone resorption in rats and mice. Bell et al. (1977) reported that a $\mathrm{Ca}: \mathrm{P}$ value of $1: 2 \cdot 4$ tended to increase parathyroid activity and bone resorption in humans.

Chronic ingestion of $\mathrm{NH}_{4} \mathrm{Cl}$ has been found to induce osteoporotic changes in dogs ( Jaffe et al. 1932) and male rats (Barzel, 1969, 1975; Barzel \& Jowsey, 1969) by stimulating osteoclastic osteolysis without compensatory changes in bone formation. Bones of animals chronically administered $\mathrm{NH}_{4} \mathrm{Cl}$ were gravimetrically, radiographically and histologically osteoporotic. However, Newell \& Beauchene (1975) found no changes in bone composition in $\mathrm{NH}_{4} \mathrm{Cl}$-fed rats although they excreted more urinary and less faecal $\mathrm{Ca}$ than control rats.

Sulphur is normally consumed in the diet as S-containing amino acids. Whiting \& Draper (1981 a) suggested that the variable calciuric effect of different proteins was related primarily to their differing $S$ amino acid content. In rats given high-protein diets, the $S$ amino acids inhibited renal tubular reabsorption of $\mathrm{Ca}$ by increasing formation and excretion of calcium sulphate salts (Whiting \& Draper, 1981 $a, b ;$ Wyshak, 1981).

The fact that postmenopausal females are four times more likely than age-matched males to have severe osteoporosis has led to the theory that the reduction in circulating oestrogens accompanying menopause is a major factor affecting development of osteoporosis (Hutchinson et al. 1979). This theory is supported by the increased incidence of osteoporosis in women with surgically induced menopause compared with age-matched, premenopausal women and by the decreased incidence of fractures of the hip and distal radius in postmenopausal women given oestrogen (Hutchinson et al. 1979, 1982). Draper et al. (1980) 
Table 1. Composition of experimental diets* $(\mathrm{g} / \mathrm{kg})$

\begin{tabular}{|c|c|c|c|c|c|}
\hline Diet... & Control & HI-P & HI-S & $\mathrm{HI}-\mathrm{NH}_{4} \mathrm{Cl}$ & MED-P \\
\hline \multicolumn{6}{|l|}{ Component } \\
\hline Calcium & 6 & 6 & 6 & 6 & 6 \\
\hline Phosphorus & 3 & 12 & 3 & 3 & 6 \\
\hline Maize starch & 306.1 & 285.4 & 298.9 & $306 \cdot 1$ & $370 \cdot 7$ \\
\hline Glucose & 356 & 356 & 356 & 356 & 356 \\
\hline Cellulose & 25 & 25 & 25 & 25 & 25 \\
\hline Maize oil ${ }^{\dagger}$ & 50 & 50 & 50 & 50 & 50 \\
\hline Soya-bean protein $\ddagger$ & 222 & 222 & 222 & 222 & 150 \\
\hline DL-methionine & 0.5 & 0.5 & 0.5 & 0.5 & 0.5 \\
\hline Choline chloride & 1 & 1 & 1 & 1 & 1 \\
\hline Vitamin mix§ & 5 & 5 & 5 & 5 & 5 \\
\hline Salt mix $\|$ & 7.8 & 7.8 & 7.8 & $7 \cdot 8$ & 7.8 \\
\hline $\mathrm{MgCO}_{3}$ & 6.9 & $0 \cdot 2$ & - & 6.9 & 6.9 \\
\hline $\mathrm{CaCO}_{3}$ & 11.88 & - & - & 11.88 & 7.04 \\
\hline $\mathrm{Ca}\left(\mathrm{H}_{2} \mathrm{PO}_{4}\right)_{2} \cdot \mathrm{H}_{2} \mathrm{O}$ & $17 \cdot 81$ & $37 \cdot 7$ & $7 \cdot 81$ & 7.81 & 20 \\
\hline $\mathrm{Mg}_{2}\left(\mathrm{PO}_{4}\right)_{2}, 5 \mathrm{H}_{2} \mathrm{O}=$ & - & $9 \cdot 4$ & & - & - \\
\hline $\mathrm{MgSO}_{4}$ & - & - & $9 \cdot 85$ & — & - \\
\hline $\mathrm{CaSO}_{4}$ & - & - & $16 \cdot 13$ & - & - \\
\hline $\mathrm{NH}_{4} \mathrm{Cl}$ & - & - & - & $20 \cdot 0$ & - \\
\hline
\end{tabular}

* Adapted from Draper et al. (1972).

† Mazola Corn Oil, Best Foods, Englewood Cliffs, NJ.

$\ddagger$ Soya-bean protein (905456); ICN Nutritional Biochemicals, Cleveland, $\mathrm{OH}$.

$\S$ Contained $(\mathrm{g} / \mathrm{kg}$ diet $)$ : thiamin 10 , riboflavin 5 , calcium pantothenate 10 , nicotinic acid 25 , pyridoxine hydrochloride 5, menadione 1, folic acid 1, biotin 0.1, vitamin $\mathrm{B}_{12} 0 \cdot 1$. Vitamins $\mathrm{A}$ and $\mathrm{D}(18 \mu \mathrm{g} / \mathrm{g}$ diet and $1.8 \mu \mathrm{g} / \mathrm{g}$ diet respectively) were added to the maize oil.

$\|$ Contained (g/kg diet): $\mathrm{ZnCO}_{3} 0.096, \mathrm{FeSO}_{4} \cdot 7 \mathrm{H}_{2} \mathrm{O} 0 \cdot 124, \mathrm{CuSO}_{4} .5 \mathrm{H}_{2} \mathrm{O} 0 \cdot 02, \mathrm{MnSO}_{4} \cdot \mathrm{H}_{2} \mathrm{O} 0 \cdot 15, \mathrm{KI} 0 \cdot 0013$, $\mathrm{NaCl} 2 \cdot 3, \mathrm{NaCO}_{3} 1 \cdot 6, \mathrm{~K}_{2} \mathrm{CO}_{3} 3 \cdot 53$.

If Pfaltz and Bauer, Inc., Stamford, CT.

found that ovariectomizing adult rats resulted in negative Ca balances which became more positive with time. Although the mechanism by which oestrogen decreases rate of bone loss is unclear, it is thought to have an antagonistic effect on PTH (Avioli, 1981) or to alter the absorption and excretion of $\mathrm{Ca}$ and $\mathrm{P}$ (Riggs et al. 1972; Avioli, 1981), or both.

The purpose of these studies was to determine the effects of acid stress and ovariectomy on bone metabolism in young rats.

\section{EXPERIMENTAL}

\section{Expt 1}

Eighteen female weanling Sprague-Dawley-descended Crl:COBS rats (Charles Rivers Laboratories, Wilmington, MA) were maintained on a semi-synthetic gel diet containing $(\mathrm{g} / \mathrm{kg}): 6 \mathrm{Ca}$ and $3 \mathrm{P}$ until the body-weights ranged from 60 to $70 \mathrm{~g}$. At that time ovariectomies were performed on all rats. At 1 week after surgery, rats were divided into three groups with equal mean body-weights and then assigned a dietary regimen. The dietary regimens were the control diet consisting of $(\mathrm{g} / \mathrm{kg}): 6 \mathrm{Ca}$ and $3 \mathrm{P}$; the MED-P diet consisting of $(\mathrm{g} / \mathrm{kg}): 6 \mathrm{Ca}$ and $6 \mathrm{P}$; and the HI-P diet consisting of $(\mathrm{g} / \mathrm{kg}) ; 6 \mathrm{Ca}$ and 12 P. Diet compositions are shown in Table 1. Diets and distilled water were fed ad lib. Once every 2 weeks, the rats were bled from the tail and placed in metabolism cages for $48 \mathrm{~h}$ and urine collected. The urine was preserved with $0.5 \mathrm{ml}$ toluene and removed daily for freezing. The rats were killed after 10 weeks of the experimental period. Femurs were removed and frozen for later analyses. 


\section{Expt 2}

Sixty-four female weanling Sprague-Dawley-descended Crl : COBS rats were obtained from Charles Rivers Laboratories. The rats were given a semi-synthetic gel diet containing $(\mathrm{g} / \mathrm{kg}): 6 \mathrm{Ca}$ and $3 \mathrm{P}$ until body-weights ranged from 60 to $70 \mathrm{~g}$. At that time ovariectomies were performed on thirty-two of the rats. At 1 week after surgery, the ovariectomized (OVX) and intact (intact) rats were divided into four groups on the basis of equal mean body-weights and then assigned a dietary regimen. The dietary regimens were the control diet consisting of $(\mathrm{g} / \mathrm{kg}): 6 \mathrm{Ca}$ and $3 \mathrm{P}$ and no additional $\mathrm{S}$ or $\mathrm{NH}_{4} \mathrm{Cl}$; the $\mathrm{HI}-\mathrm{P}$ diet consisting of $(\mathrm{g} / \mathrm{kg})$ : $6 \mathrm{Ca}$ and $12 \mathrm{P}$ and no additional $\mathrm{S}$ or $\mathrm{NH}_{4} \mathrm{Cl}$; the $\mathrm{HI}-\mathrm{S}$ diet consisting of $(\mathrm{g} / \mathrm{kg}): 6 \mathrm{Ca}$ and $3 \mathrm{P}$ plus an additional amount of sulphate to make $10 \mathrm{~g} \mathrm{~S} / \mathrm{kg}$ diet and no additional $\mathrm{NH}_{4} \mathrm{Cl}$; and the $\mathrm{HI}-\mathrm{NH}_{4} \mathrm{Cl}$ diet consisting of $(\mathrm{g} / \mathrm{kg}) ; 6 \mathrm{Ca}$ and $\mathrm{P}$ plus an additional $20 \mathrm{NH}_{4} \mathrm{Cl}$ and no additional sulphate. Diet compositions are given in Table 1. Diet and distilled water were fed ad lib.

Rats were bled from the tail after 3,6 and 9 weeks. After 4 and 8 weeks, they were placed in metabolism cages and $24 \mathrm{~h}$ urine and faecal collections obtained. After 10 weeks, rats were killed and femurs dissected out.

\section{Analyses}

Urine, faecal and plasma samples were analysed for Ca (Perkin-Elmer Corp., 1966) and $\mathrm{P}$ (Chen et al. 1956) by standard techniques. Femurs were cleaned of all adhering soft tissue, defatted in chloroform-methanol $(2: 1 \mathrm{v} / \mathrm{v})$, dried, weighed and pulverized. Portions were wet ashed (Neidermeir et al. 1971) and analysed for Ca (Perkin-Elmer Corp., 1966) and $\mathrm{P}$ (Chen et al. 1956). Femurs and urine were also analysed for hexosamines (Gatt \& Berman, 1966) and hydroxyproline (HOP) (Bergman \& Loxley, 1970). Urine was analysed for sulphate by the method of Swaroop (1973) and for creatinine by the method of Folin (Henry, 1967).

The Statistical Analysis System (Barr, 1976), a computer software package, was used to perform statistical analyses. Means were adjusted using a least square procedure. The general linear-model prodedure was used in determining the associations among diet and surgical status and each of the other variables.

Statistical significance of differences was based on the probability of a type I error set at $P<0.05$ level. Whenever no significant differences were found between values for OVX and intact rats given a particular diet, the values were pooled.

\section{RESULTS}

Expt 1

Ovariectomized rats were given diets containing $(\mathrm{g} / \mathrm{kg}): 6 \mathrm{Ca}$ and 3,6 or $12 \mathrm{P}$ for 10 weeks (control, MED-P and HI-P diets respectively). Serum Ca levels were significantly different $(P<0.05)$ only after 10 weeks of the experimental period (Table 2$)$. At this time, the control-fed rats had higher serum Ca concentrations than the MED-P-fed rats, with both groups having higher values than that for the HI-P-fed rats. The mean serum $\mathrm{Ca}$ level in the HI-P-fed rats was lower than the normal range. Serum $\mathbf{P}$ values differed significantly at 2, 6 and 10 weeks. At 2 weeks the control-fed rats had lower serum $P$ concentrations than the HI-P-fed rats; at 6 weeks, the MED-P-fed rats had higher mean serum P values than the other groups. After 10 weeks, mean values for all three groups were significantly different with control-fed rats having the lowest and HI-P-fed rats having the highest level of serum $\mathbf{P}$.

Table 3 presents mean $48 \mathrm{~h}$ urinary excretion of $\mathrm{Ca}, \mathrm{P}$ and HOP. Urinary $\mathrm{Ca}$ was greater for the control-fed rats than for the other groups after 2, 6, 8 and 10 weeks. Urinary $P$ was greatest in the HI-P-fed groups after 2, 6, 8 and 10 weeks. At 4 weeks, MED-P-fed and 
Table 2. Expt 1. Serum calcium and phosphorus concentrations of ovariectomized rats given diets differing in phosphate content

(Mean values with their standard errors)

\begin{tabular}{|c|c|c|c|c|c|}
\hline \multirow{2}{*}{$\begin{array}{c}\text { Diet* } \\
(\mathrm{Ca}: \mathrm{P})\end{array}$} & \multirow{2}{*}{$\begin{array}{l}\text { Period } \\
\text { of } \\
\text { treatment } \\
\text { (weeks) }\end{array}$} & \multicolumn{2}{|c|}{$\underset{(\mathrm{mg} / \mathrm{l})}{\mathrm{Ca}}$} & \multicolumn{2}{|c|}{$\begin{array}{c}\mathrm{P} \\
(\mathrm{mg} / \mathrm{l})\end{array}$} \\
\hline & & Mean & SE & Mean & $\mathrm{SE}$ \\
\hline Control & 2 & 90 & 5 & $52^{\mathrm{a}}$ & 4 \\
\hline$(2 \cdot 0)$ & 4 & 90 & 1 & 61 & 5 \\
\hline & 6 & 103 & 1 & $63^{a}$ & 3 \\
\hline & 8 & 87 & 1 & 66 & 7 \\
\hline & 10 & $97^{\mathrm{a}}$ & 2 & $42^{\mathrm{a}}$ & 3 \\
\hline MED-P & 2 & 99 & 4 & $60^{a, b}$ & 3 \\
\hline$(1 \cdot 0)$ & 4 & 87 & 3 & 72 & 4 \\
\hline & 6 & 99 & 3 & $85^{\mathrm{b}}$ & 7 \\
\hline & 8 & 58 & 2 & 65 & 2 \\
\hline & 10 & $87^{\mathrm{b}}$ & 2 & $54^{b}$ & 3 \\
\hline HI-P & 2 & 90 & 4 & $66^{\mathrm{b}}$ & 3 \\
\hline$(0.5)$ & 4 & 87 & 2 & 69 & 9 \\
\hline & 6 & 98 & 1 & $77^{\mathrm{a}}$ & 3 \\
\hline & 8 & 87 & 2 & 65 & 3 \\
\hline & 10 & $79^{\mathrm{c}}$ & 3 & $79^{\mathrm{c}}$ & 5 \\
\hline
\end{tabular}

a,b,e Values within columns with common superscript letters at any particular week were not significantly different $(P>0.05)$.

* Diet compositions were $(\mathrm{g} / \mathrm{kg})$ : control, $6 \mathrm{Ca}+3 \mathrm{P}$; MED-P, $6 \mathrm{Ca}+6 \mathrm{P}$; HI-P, $6 \mathrm{Ca}+12 \mathrm{P}$. For details, see Table 1 and p. 80 .

Table 3. Expt 1. Urinary excretion of calcium, phosphorus and hydroxyproline of ovariectomized rats given diets differing in phosphate content

(Mean values with their standard errors)

\begin{tabular}{|c|c|c|c|c|c|c|c|}
\hline \multirow{2}{*}{$\begin{array}{c}\text { Diet* }^{*} \\
\text { (Ca:P) }\end{array}$} & \multirow{2}{*}{$\begin{array}{l}\text { Period } \\
\text { of } \\
\text { treatment } \\
\text { (weeks) }\end{array}$} & \multicolumn{2}{|c|}{$\begin{array}{c}\mathrm{Ca} \\
(\mathrm{mg} / 48 \mathrm{~h})\end{array}$} & \multicolumn{2}{|c|}{$\underset{(\mathrm{mg} / 48 \mathrm{~h})}{\mathrm{P}}$} & \multicolumn{2}{|c|}{$\begin{array}{l}\text { Hydroxyproline } \\
\text { (mg/48 h) }\end{array}$} \\
\hline & & Mean & $\mathrm{SE}$ & Mean & $\mathrm{SE}$ & Mean & $\mathrm{SE}$ \\
\hline $\begin{array}{c}\text { Control } \\
(2 \cdot 0)\end{array}$ & $\begin{array}{r}2 \\
4 \\
6 \\
8 \\
10\end{array}$ & $\begin{array}{l}212^{\mathrm{a}} \\
341 \\
281^{\mathrm{a}} \\
217^{\mathrm{a}} \\
218^{\mathrm{a}}\end{array}$ & $\begin{array}{r}2 \\
123 \\
43 \\
38 \\
36\end{array}$ & $\begin{array}{r}7^{\mathrm{a}} \\
12^{\mathrm{a}} \\
16^{\mathrm{a}} \\
72^{\mathrm{a}} \\
98^{\mathrm{a}}\end{array}$ & $\begin{array}{r}3 \\
5 \\
5 \\
23 \\
63\end{array}$ & $\begin{array}{l}954^{\mathrm{a}, \mathrm{b}} \\
773 \\
768^{\mathrm{a}} \\
654 \\
786^{\mathrm{a}, \mathrm{b}}\end{array}$ & $\begin{array}{r}55 \\
68 \\
55 \\
105 \\
52\end{array}$ \\
\hline $\begin{array}{c}\text { MED-P } \\
(1 \cdot 0)\end{array}$ & $\begin{array}{r}2 \\
4 \\
6 \\
8 \\
10\end{array}$ & $\begin{array}{c}114^{\mathrm{b}} \\
120 \\
72^{\mathrm{b}} \\
53^{\mathrm{b}} \\
91^{\mathrm{b}}\end{array}$ & $\begin{array}{l}38 \\
51 \\
29 \\
17 \\
10\end{array}$ & $\begin{array}{l}287^{\mathrm{a}} \\
813^{\mathrm{b}} \\
464^{\mathrm{b}} \\
485^{\mathrm{b}} \\
288^{\mathrm{a}}\end{array}$ & $\begin{array}{r}44 \\
229 \\
98 \\
94 \\
56\end{array}$ & $\begin{array}{l}719^{\mathrm{a}} \\
872 \\
722^{\mathrm{a}} \\
725 \\
551^{\mathrm{a}}\end{array}$ & $\begin{array}{r}47 \\
116 \\
60 \\
143 \\
69\end{array}$ \\
\hline $\begin{array}{l}\text { HI-P } \\
(0.5)\end{array}$ & $\begin{array}{r}2 \\
4 \\
6 \\
8 \\
10\end{array}$ & $\begin{array}{c}84^{\mathrm{b}} \\
97 \\
73^{\mathrm{b}} \\
72^{\mathrm{b}} \\
126^{\mathrm{b}}\end{array}$ & $\begin{array}{l}15 \\
26 \\
11 \\
32 \\
32\end{array}$ & $\begin{array}{r}1544^{\mathrm{b}} \\
985^{\mathrm{b}} \\
1296^{\mathrm{c}} \\
1187^{\mathrm{c}} \\
987^{\mathrm{b}}\end{array}$ & $\begin{array}{l}589 \\
226 \\
275 \\
171 \\
147\end{array}$ & $\begin{array}{c}1211^{\mathrm{b}} \\
1355 \\
1074^{\mathrm{b}} \\
1013 \\
854^{\mathrm{b}}\end{array}$ & $\begin{array}{l}198 \\
328 \\
120 \\
164 \\
114\end{array}$ \\
\hline
\end{tabular}

$a, b, c$ Values within columns with common superscript letters at any particular week were not significantly different $(P>0 \cdot 05)$.

* Diet compositions were $(\mathrm{g} / \mathrm{kg})$ : control, $6 \mathrm{Ca}+3 \mathrm{P}$; MED-P, $6 \mathrm{CA}+6 \mathrm{P}$; HI-P, $6 \mathrm{CA}+12 \mathrm{P}$. For details, see Table $\mathrm{I}$ and p. 80 . 
Table 4. Expt. 1. Femur composition of ovariectomized rats given diets differing in phosphate content

(Mean values with their standard errors)

\begin{tabular}{|c|c|c|c|c|c|c|c|c|c|c|}
\hline \multirow[b]{3}{*}{$\operatorname{Diet}^{*}(\mathrm{Ca}: \mathrm{P})$} & \multicolumn{10}{|c|}{ Femur content (mg/femur) } \\
\hline & \multicolumn{2}{|c|}{$\mathrm{Ca}$} & \multicolumn{2}{|c|}{$\mathbf{P}$} & \multicolumn{2}{|c|}{ Hydroxyproline } & \multicolumn{2}{|c|}{ Hexosamines } & \multicolumn{2}{|c|}{$\mathrm{Ca}: \mathrm{P}$} \\
\hline & Mean & $\mathrm{SE}$ & Mean & SE & Mean & $\mathrm{SE}$ & Mean & $\mathrm{SE}$ & Mean & $\mathrm{SE}$ \\
\hline Control $(2 \cdot 0)$ & 67.04 & $5 \cdot 18$ & $35 \cdot 14$ & $2 \cdot 58$ & $7 \cdot 22$ & 0.70 & $828 \cdot 9$ & 107.4 & 1.92 & $0 \cdot 11$ \\
\hline MED-P $(1 \cdot 0)$ & $61 \cdot 63$ & 3.09 & $34 \cdot 43$ & 1.98 & $6 \cdot 22$ & $0 \cdot 38$ & $979 \cdot 3$ & $51 \cdot 6$ & 1.92 & 0.07 \\
\hline HI-P $(0 \cdot 5)$ & 55.04 & 1.03 & $32 \cdot 6$ & $1 \cdot 26$ & 5.43 & $0 \cdot 34$ & $1026 \cdot 4$ & $75 \cdot 5$ & 1.7 & 0.06 \\
\hline
\end{tabular}

* Diet compositions were (g/kg): control, $6 \mathrm{Ca}+3 \mathrm{P}$; MED-P, $6 \mathrm{Ca}+6 \mathrm{P} ; \mathrm{HI}-\mathrm{P}, 6 \mathrm{Ca}+12 \mathrm{P}$. For details, see Table 1 and p. 80 .

Table 5. Expt 2. Effects of dietary phosphate, sulphate and ammonium chloride on urinary calcium, phosphorus, sulphate and creatinine in intact and ovariectomized rats*

(Least square means with their standard errors; pooled values for intact and ovariectomized rats)

\begin{tabular}{|c|c|c|c|c|c|c|c|c|c|}
\hline \multirow[b]{2}{*}{ Diet* } & \multirow{2}{*}{$\begin{array}{c}\text { Period } \\
\text { of } \\
\text { treatment } \\
\text { (weeks) }\end{array}$} & \multicolumn{2}{|c|}{$\underset{(\mathrm{mg} / 24 \mathrm{~h})}{\mathrm{Ca}}$} & \multicolumn{2}{|c|}{$\underset{(\mathrm{mg} / 24 \mathrm{~h})}{\mathrm{P}}$} & \multicolumn{2}{|c|}{$\begin{array}{l}\text { Sulphate } \\
(\mathrm{g} / 24 \mathrm{~h})\end{array}$} & \multicolumn{2}{|c|}{$\begin{array}{l}\text { Creatinine } \\
(\mathrm{mg} / 24 \mathrm{~h})\end{array}$} \\
\hline & & Mean & $\mathrm{SE}$ & Mean & $\mathrm{SE}$ & Mean & $\mathrm{SE}$ & Mean & $\mathrm{SE}$ \\
\hline Control & $\begin{array}{l}4 \\
8\end{array}$ & $\begin{array}{l}0.71^{a} \\
1 \cdot 14^{a, c}\end{array}$ & $\begin{array}{l}0.18 \\
0.21\end{array}$ & $\begin{array}{l}7.21^{\mathrm{a}} \\
6.75^{\mathrm{a}}\end{array}$ & $\begin{array}{l}4.75 \\
7.23\end{array}$ & $\begin{array}{l}356 \cdot 0^{\mathrm{a}} \\
242 \cdot 8^{\mathrm{a}}\end{array}$ & $\begin{array}{l}203 \cdot 6 \\
249 \cdot 3\end{array}$ & $\begin{array}{l}7.41^{a} \\
6 \cdot 61^{a}\end{array}$ & $\begin{array}{l}0.35 \\
0.27\end{array}$ \\
\hline HI-P & $\begin{array}{l}4 \\
8\end{array}$ & $\begin{array}{l}0.41^{a} \\
0.51^{a}\end{array}$ & $\begin{array}{l}0 \cdot 18 \\
0 \cdot 24\end{array}$ & $\begin{array}{l}100 \cdot 63^{b} \\
157 \cdot 48^{b}\end{array}$ & $\begin{array}{l}4 \cdot 75 \\
8 \cdot 15\end{array}$ & $\begin{array}{l}609 \cdot 3^{a} \\
437 \cdot 2^{a}\end{array}$ & $\begin{array}{l}203 \cdot 6 \\
281 \cdot 7\end{array}$ & $\begin{array}{l}5.75^{b} \\
5 \cdot 41^{b}\end{array}$ & $\begin{array}{l}0.35 \\
0.31\end{array}$ \\
\hline HI-S & $\begin{array}{l}4 \\
8\end{array}$ & $\begin{array}{l}2 \cdot 70^{\mathrm{b}} \\
1 \cdot 25^{\mathrm{c}}\end{array}$ & $\begin{array}{l}0.17 \\
0.22\end{array}$ & $\begin{array}{r}8 \cdot 60^{a} \\
11 \cdot 79^{a}\end{array}$ & $\begin{array}{l}4.75 \\
7 \cdot 52\end{array}$ & $\begin{array}{l}2596 \cdot 4^{b} \\
1364 \cdot 1^{b}\end{array}$ & $\begin{array}{l}203 \cdot 6 \\
259 \cdot 6\end{array}$ & $\begin{array}{l}6 \cdot 88^{\mathrm{a}, \mathrm{b}, \mathrm{c}} \\
5 \cdot 18^{\mathrm{b}}\end{array}$ & $\begin{array}{l}0.35 \\
0.28\end{array}$ \\
\hline $\mathrm{HI}-\mathrm{NH}_{4} \mathrm{Cl}$ & $\begin{array}{l}4 \\
8\end{array}$ & $\begin{array}{l}2 \cdot 24^{b} \\
2 \cdot 24^{b}\end{array}$ & $\begin{array}{l}0.18 \\
0.23\end{array}$ & $\begin{array}{l}8 \cdot 11^{\mathrm{a}} \\
9 \cdot 27^{\mathrm{a}}\end{array}$ & $\begin{array}{l}4.75 \\
7.86\end{array}$ & $\begin{array}{l}283 \cdot 3^{\mathrm{a}} \\
349 \cdot 2^{\mathrm{a}}\end{array}$ & $\begin{array}{l}203 \cdot 6 \\
271 \cdot 4\end{array}$ & $\begin{array}{l}6 \cdot 37^{\mathrm{b}, c} \\
6.35^{\mathrm{a}}\end{array}$ & $\begin{array}{l}0.35 \\
0.30\end{array}$ \\
\hline
\end{tabular}

a. $h$, Values within columns with common superscript letters at any particular week were not significantly different $(P>0 \cdot 05)$.

* Diet compositions were (g/kg): control, $6 \mathrm{Ca}+3 \mathrm{P} ; \mathrm{HI}-\mathrm{P}, 6 \mathrm{Ca}+12 \mathrm{P} ; \mathrm{HI}-\mathrm{S}, 6 \mathrm{Ca}+3 \mathrm{P}+10 \mathrm{~S} ; \mathrm{HI}_{-} \mathrm{NH}_{4} \mathrm{Cl}$, $6 \mathrm{Ca}+3 \mathrm{P}+20 \mathrm{NH}_{4} \mathrm{Cl}$. For details, see Table 1 and p. 80 .

HI-P-fed rats excreted significantly more urinary $P$ than did control-fed rats. HOP excretion showed no clearly defined trends although the HI-P-fed rats excreted more than MED-P-fed rats; at 2, 6 and 10 weeks, HOP excretion for the control groups was statistically similar to that for the other groups.

Values describing the femur composition from rats in Expt 1 is given in Table 4. There were no significant differences in femur $\mathrm{Ca}, \mathrm{P}, \mathrm{HOP}$ or hexosamines when values were expressed on a weight/femur basis, although the HI-P-fed rats tended to have less $\mathrm{Ca}, \mathrm{P}$ and HOP and more hexosamines than the other groups. Since the HI-P-fed rats had lower body-weights than the other groups, these trends may reflect body-weight differences.

\section{Expt 2}

Intact and OVX rats were given diets containing (g/kg): $6 \mathrm{Ca}$ and $12 \mathrm{P}(\mathrm{HI}-\mathrm{P}), 20$ sulphate (HI-S) or $20 \mathrm{NH}_{4} \mathrm{Cl}\left(\mathrm{HI}-\mathrm{NH}_{4} \mathrm{Cl}\right)$ for 12 weeks. There were no significant differences between 
Table 6. Expt 2. Effects of dietary phosphate, sulphate and ammonium chloride on femur calcium, phophorus and hydroxyproline ( $\mathrm{mg} / \mathrm{femur}$ per $\mathrm{kg}$ body-weight) in intact $(\mathrm{I})$ and ovariectomized $(O)$ rats

(Least square means with their standard errors)

\begin{tabular}{|c|c|c|c|c|c|c|c|}
\hline \multirow[b]{2}{*}{ Diet* } & \multirow{2}{*}{$\begin{array}{c}\text { Surgical } \\
\text { status }\end{array}$} & \multicolumn{2}{|c|}{$\mathrm{Ca}$} & \multicolumn{2}{|c|}{$\mathbf{P}$} & \multicolumn{2}{|c|}{ Hydroxyproline } \\
\hline & & Mean & $\mathrm{SE}$ & Mean & $\mathrm{SE}$ & Mean & SE \\
\hline Control & $\begin{array}{l}\mathrm{I} \\
\mathrm{O}\end{array}$ & $\begin{array}{l}263 \cdot 7^{\mathrm{a}} \\
221 \cdot 7^{\mathrm{b}}\end{array}$ & $\begin{array}{l}11 \cdot 2 \\
11 \cdot 2\end{array}$ & $\begin{array}{l}183 \cdot 7^{\mathrm{a}} \\
158 \cdot 9^{\mathrm{a}}\end{array}$ & $\begin{array}{l}7 \cdot 5 \\
7 \cdot 5\end{array}$ & $36 \cdot 6^{a}$ & $3 \cdot 0$ \\
\hline HI-P & $\begin{array}{l}\text { I } \\
\text { O }\end{array}$ & $\begin{array}{l}250 \cdot 7^{\mathrm{a}} \\
260 \cdot 0^{\mathrm{a}}\end{array}$ & $\begin{array}{l}12 \cdot 1 \\
11 \cdot 2\end{array}$ & $\begin{array}{l}189 \cdot 4^{\mathrm{a}} \\
152 \cdot 2^{\mathrm{b}}\end{array}$ & $\begin{array}{l}8.0 \\
7.5\end{array}$ & $36 \cdot 5^{\mathrm{a}}$ & $3 \cdot 1$ \\
\hline HI-S & $\begin{array}{l}\text { I } \\
\text { O }\end{array}$ & $\begin{array}{l}264 \cdot 8^{a} \\
218 \cdot 7^{b}\end{array}$ & $\begin{array}{l}11 \cdot 2 \\
11 \cdot 2\end{array}$ & $\begin{array}{l}188 \cdot 8^{\mathrm{a}} \\
152 \cdot 2^{\mathrm{a}}\end{array}$ & $\begin{array}{l}7 \cdot 5 \\
7 \cdot 5\end{array}$ & $36 \cdot 1^{a}$ & $3 \cdot 0$ \\
\hline $\mathrm{HI}-\mathrm{NH}_{4} \mathrm{Cl}$ & $\begin{array}{l}1 \\
O\end{array}$ & $\begin{array}{l}259 \cdot 3^{\mathrm{a}} \\
228 \cdot 0^{\mathrm{b}}\end{array}$ & $\begin{array}{l}11 \cdot 2 \\
11 \cdot 2\end{array}$ & $\begin{array}{l}172 \cdot 9^{\mathrm{a}} \\
164 \cdot 5^{\mathrm{b}}\end{array}$ & $\begin{array}{l}7.5 \\
7.5\end{array}$ & $35 \cdot 0^{\mathrm{a}}$ & $3 \cdot 0$ \\
\hline
\end{tabular}

a,b Values within columns with common superscript letters were not significantly different $(P>0 \cdot 05)$.

* Diet compositions were $(\mathrm{g} / \mathrm{mg})$ : control, $6 \mathrm{Ca}+3 \mathrm{P}$; HI-P, $6 \mathrm{Ca}+12 \mathrm{P}$; HI-S, $6 \mathrm{Ca}+3 \mathrm{P}+10 \mathrm{~S} ; \mathrm{HI}_{-} \mathrm{NH}_{4} \mathrm{Cl}$, $6 \mathrm{Ca}+3 \mathrm{P}+20 \mathrm{NH}_{4} \mathrm{Cl}$. For details, see Table 1 and p. 81 .

intact and OVX rats in serum $\mathrm{Ca}$ and $\mathrm{P}$ values, therefore, those values were pooled. Mean serum $\mathrm{Ca}$ values were significantly $(P<0.05)$ less for rats given the HI-P-diet at 3,6 and 9 weeks than for the other groups. Serum $P$ values were significantly higher for the HI-P-fed rats than for the other groups at 6 and 9 weeks.

Intact and OVX rats also did not differ in urinary excretion of $\mathrm{Ca}, \mathrm{P}$, sulphate, creatinine and HOP; therefore, values presented in Table 5 are pooled means. $\mathrm{HI}-\mathrm{S}$ - and $\mathrm{HI}-\mathrm{NH}_{4} \mathrm{Cl}-\mathrm{fed}$ rats excreted more $\mathrm{Ca}$ at 4 and 8 weeks than did control and HI-P-fed rats. At 8 weeks the $\mathrm{HI}-\mathrm{NH}_{4} \mathrm{Cl}$-fed rats excreted more $\mathrm{Ca}$ than did the other groups. HI-P-fed rats excreted significantly more $P$ in the urine than the other groups at 4 and 8 weeks. At 8 weeks, urinary creatinine was higher in the control and $\mathrm{HI}-\mathrm{NH}_{4} \mathrm{Cl}-\mathrm{fed}$ rats than in the other groups. Urinary HOP excretion at 8 weeks did not differ among the groups, although the HI-P-fed rats tended to excrete more than rats given the other diets.

Table 6 presents femur composition values for the rats. OVX rats given the control, HI-S or $\mathrm{HI}-\mathrm{NH}_{4} \mathrm{Cl}$ diets had less femur $\mathrm{Ca}$ and $\mathrm{P}$ than did intact rats given similar diets or the intact or OVX HI-P-fed rats. Neither ovariectomy nor dietary treatment resulted in any significant changes in femur HOP.

\section{DISCUSSION}

The depression of serum $\mathrm{Ca}$ with elevation of serum $\mathrm{P}$ seen in the rats given the HI-P diet agrees with the findings of other researchers (Newell \& Beauchene, 1975; Whiting \& Draper, 1980). Draper et al. (1972) reported stimulation of PTH secretion in animals given the HI-P diet which resulted from the mild hyperphosphataemia and hypocalcaemia.

The dramatic increase in urinary $P$ seen in the HI-P-fed rats indicates that urine is the primary route of excretion for $P$ in the rat. Faecal $P$ for the HI-P-fed rats in Expt 2 was higher than that of the other groups; however, the differences were not as pronounced as those for urinary excretion. The fact that the HI-S and $\mathrm{HI}-\mathrm{NH}_{4} \mathrm{Cl}$ groups excreted more urinary $\mathrm{Ca}$ than control or $\mathrm{HI}-\mathrm{P}$-fed rats indicates that sulphate and $\mathrm{NH}_{4} \mathrm{Cl}$ may be more 
involved in hypercalciuric responses than $\mathrm{P}$. These findings support findings of other researchers (Jaffe et al. 1932; Whiting \& Draper, 1980; Newell \& Beauchene, 1975). At 8 weeks faecal Ca was less for the HI-S-fed rats than for the other groups, indicating some compensation for the increased urinary excretion associated with this diet; there was no similar compensation evident in the $\mathrm{HI}-\mathrm{NH}_{4} \mathrm{Cl}$ group.

The lower femur $\mathrm{Ca}$ and $\mathrm{P}$ in the $\mathrm{OVX}$ rats given the $\mathrm{HI}-\mathrm{S}$ and $\mathrm{HI}-\mathrm{NH}_{4} \mathrm{Cl}$ diets tends to support the theory of Wachman \& Bernstein (1968) that dietary acids may induce osteoporotic-like lesions and the findings of Barzel (1969) that $20 \mathrm{~g} \mathrm{NH}_{4} \mathrm{Cl} / \mathrm{kg}$ induced osteoporosis. The lower femur Ca levels in OVX rats given the HI-S diets agrees with the findings of Whiting \& Draper (1980). It should be noted that the bone resorption reported by the latter researchers abated in approximately 2 months, a time-period similar to that used in the present studies. Given the compensation for Ca loss noted in the HI-S-fed rats in the present study, a similar phenomenon may have occurred had the study extended longer than 10 weeks. The lack of bone changes in rats given the HI-P diet may indicate that phosphate is not as involved in the acid-stress system as previously thought, at least at the level used in the present study. This observation contradicts other findings with rats (Whiting \& Draper, 1980) but supports some previous work in humans (Draper et al. 1980; Hegsted et al. 1981; Heaney \& Recher 1982). However, Whiting \& Draper (1980) used older rats and fed them for a longer period of time than those used in the present experiments, and age of the rat or duration of the experiment, or both, may have had a significant effect on bone mineral concentrations.

The bone matrix components, HOP and hexosamines, did not differ significantly in the present studies, even though $\mathrm{Ca}$ and $\mathbf{P}$ values were altered in Expt 2 . This may be explained on the basis of the more rapid turnover rate associated with amorphous calcium phosphate salts compared with apatitic crystals (Glimcher, 1984). Posner (1973) reviewed available information and suggested that bones from young animals may contain more amorphous salts than those from older animals. Therefore, the use of young rats in the present studies may account for the alterations seen in $\mathrm{Ca}$ and $\mathrm{P}$ values without concomitant alterations in matrix constituents. The present findings also suggest that diet has a greater effect than oestrogen on serum and urinary $\mathrm{Ca}$ while oestrogen affects bone $\mathrm{Ca}$ and $\mathrm{P}$ values, at least in rats given $\mathrm{HI}-\mathrm{S}$ and $\mathrm{HI}-\mathrm{NH}_{4} \mathrm{Cl}$ diets. This implies either a protective effect of oestrogen on bone resorption or a facilitative effect of oestrogen on bone deposition. It has been previously reported that oestrogen has an antagonistic effect on such bone-resorbing hormones as PTH (Avioli, 1981).

Dietary acid stress provided by sulphate and $\mathrm{NH}_{4} \mathrm{Cl}$ appeared to affect bone mineral metabolism in young female OVX rats. There was no effect of feeding HI-P diets on bones of OVX rats or of feeding any of the diets on bones of intact rats.

\section{REFERENCES}

Avioli, L.V. (1981). Federation Proceedings 40, 2481-2422.

Barr, A. J. (1976). Statistical Analysis System. Raleigh, NC: SAS Institute, Inc.

Barzel, U. S. (1969). Calcified Tissue Research 4, 94-100.

Barzel, U. S. (1975). Endocrinology 96, 1304-1306.

Barzel, U. S. \& Jowsey, J. (1969). Clinical Science 36, 517-524.

Bell, R. R., Draper, H. H., Tzeng, D. Y. M., Shin, H. K. \& Schmidt, R. (1977). Journal of Nutrition 107, 42-50.

Bergman, I. \& Loxley, R. (1970). Clinica Chimica Acta 27, 347-349.

Chen, P. S., Torivara, T. Y. \& Warner, H. (1956). Analytical Chemistry 28, 1756-1758.

Draper, H. H., Bell, R. R. \& Shin, K. S. (1980). Journal of Nutrition 110, 778-783.

Draper, H. H., Sie, T. L. \& Bergan, J. G. (1972). Journal of Nutrition 102, 1133-1142.

Gatt, R. \& Berman, E. R. (1966). Analytical Biochemistry 15, 167.

Glimcher, M. J. (1984). Philosophical Transactions of the Royal Society of London 304, 479-508.

Heaney, R. P. \& Recker, R. R. (1982). Journal of Laboratory Clinical Medicine 99, 46-55. 
Hegsted, M., Schuette, S. A. I., Zemel, M. B. \& Linkswiler, H. M. (1981). Journal of Nutrition 11, 553-562. Henry, R. J. (ed.) (1967). In Clinical Chemistry Principles and Techniques. New York: Harper and Row. Hutchinson, T. A., Polansky, J. M. \& Feinstein, A. R. (1979). Lancet ii, 705-709.

Hutchinson, T. A., Polansky, J. M. \& Feinstein, A. R. (1982). Nutrition Reviews 40, 13-15.

Jaffe, H. L., Bodansey, A. \& Chandler, J. P. (1932). Journal of Experimental Medicine 56, 823-828.

Newell, G. K. \& Beauchene, R. E. (1975). Journal of Nutrition 105, 1039-1047.

Niedermeir, W., Griggs, J. H. \& Johnson, R. S. (1971). Applied Spectrophotometry 25, 53-56.

Perkin-Elmer Corp. (1966). Supplement to Analytical Methods for Atomic Absorption Spectrophotometry. Norfolk, Conn: Perkin-Elmer Corp.

Posner, A. S. (1973). Federation Proceedings 32, 1933-1937.

Riggs, B. L., Jowsey, J., Goldsmith, R. S., Kelly, P. J., Hoffman, D. L. \& Arnaud, C. D. (1972). Journal of Clinical Investigation 51, 1659-1663.

Swaroop, A. (1973). Clinica Chimica Acta 46, 333-336.

Wachman, A. \& Bernstein, D. D. (1968). Lancet i, 958-959.

Whiting, S. J. \& Draper, H. H. (1980). Journal of Nutrition 110, 212-222.

Whiting. S. J. \& Draper, H. H. (1981 a). Journal of Nutrition 111, 1721-1726.

Whiting, S. J. \& Draper, H. H. (1981 b). Nutrition Reviews 39, 11-13.

Wyshak, G. (1981). Journal of Gerontology 36, 424-426. 